\begin{tabular}{|c|c|}
\hline 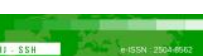 & Malaysian Journal of Social Sciences and Humanities (MJSSH) \\
\hline Malaysian Journal of & Volume 6, Issue 8, August 2021 \\
\hline (MJ-SSH) & e-ISSN : 2504-8562 \\
\hline & $\begin{array}{l}\text { Journal home page: } \\
\text { www.msocialsciences.com }\end{array}$ \\
\hline
\end{tabular}

\title{
Domestication as Strategy in Translating Religious Cultural Elements into English
}

\author{
Sulhah Ramli' ${ }^{\text {, Arnida A. Bakar }}{ }^{1}$ \\ 1Faculty of Major Language Studies, Universiti Sains Islam Malaysia (USIM) \\ Correspondence: Sulhah Ramli (sulhah@usim.edu.my)
}

\begin{abstract}
People with different beliefs and religions around the world discovered that Quran enlightens the way of life. Therefore, it results in emergence of progressive efforts of translating this sacred text into many languages that has been carried out particularly in $20^{\text {th }}$ century. However, translating sacred text is far more difficult than other type of texts. There are religious culture-specific-items that carry peculiar meaning and must be translated into appropriate equivalent in target culture. Thus, the meaning encompassed in that equivalent, and the description that characterized the meaning will be compatible with its original. Moreover, translating these items by applying domestication strategy will bring the text close to the target reader. It is because the equivalent provided in target language is familiar and wellknown to the readership. Yet, this strategy puts the cultural gap to its intended meaning, especially when the text is related to the religious culture-specific-item, which is only known to the source readership. Therefore, the present article aims to investigate the domestication strategy in translating religious cultural elements into English. This study is qualitative, and the data are analyzed descriptively using document analysis. Disclosing the meaning of domesticated equivalent, the study adopts componential analysis by Newmark (1988). The study contributes to enhancing the procedure of componential analysis by validating the cultural element categorization with experts and referring exegesis as main source in identifying the characteristic of meaning. It is found that domestication strategy can only provide the adequate meaning to the closest when it comes together with compensation strategy.
\end{abstract}

Keywords: strategy, Quran, religion, cultural gap, componential analysis

\section{Introduction}

The Quran embraces universal values and virtues. People with different beliefs and religions around the world discovered that these fundamentals lead them to harmonious life. The importance of the Quran encourages its translation activity whereby the earliest activity of Quran translation has started in $12^{\text {th }}$ century. First Quran translation into European languages was carried out by Robert of Ketton in 1143 (Gazquez \& Gray, 2007; Elmarsafy, 2009; Abobaker Ali Brakhw \& Sharifah Fazliyaton Shaik Ismail, 2014). The early effort of non-Muslim translator encouraged Muslim outside the Arab world to translate Quran into their languages. The importance of Quran as a sacred text of Muslim non-Arab is an essential motivation for this initiative. 


\section{Literature Review}

\section{Quran Translation}

The translation of the meaning of the Quran into non-Arabic languages becomes a necessity, especially as an approach to deliver the message of the Quran to other non-Arab Muslim population across the globe. As stated in BBC News (2017) that Islam is the most growing religion in the world. In the other hand, this divine Scripture can bring them closer to the Quran and simultaneously they will try to learn the Arabic language to understand its messages and teachings (Mohd Shukri Hanapi, 2001). Without the Quranic translation, it is certainly difficult to imagine an effective way to convey its virtues either to the Muslim and non-Muslim (Ahmad Bazli Ahmad Hilmi, 2014). Thus, the translation of this divine Scripture into other languages is not only important so that its messages and teachings can be spread to all Muslim in the world, but also can govern the global harmony through the humanitarian virtues.

The early translation of the Qur'an had already begun during the prophet's time which was performed by Salman al-Farisiy who translated al-Fatihah chapter into Persian language (Iman Najim \& M.Y. Zulkifli, 2012). Some scholar assumed that the first Quran translation in Europe was published in $16^{\text {th }}$ by Theodore Bibliander (1543) in Latin (Ahmad von Denffer, 2010). However, some found its translation has been established in $12^{\text {th }}$ century (Gazquez \& Gray, 2007; Elmarsafy, 2009; Abobaker Ali Brakhw \& Sharifah Fazliyaton Shaik Ismail, 2014). Since then, many efforts have been accomplished to translate the meaning of Quran into different languages in the world. In other hand, Islam as a way of life has become the world's fastest growing religion according to research published by Pew Research Center as reported by BBC News (British Broadcasting Corporation, 2017). It is a religion that has highest fertility rates and expected to increase in number in period between 2015 and 2060 (Hacket \& Lipka, 2018). This statement clearly indicates that translation of Quran into other languages is necessary because of the future increasement rates of Islam believers all around the world.

It is found that some scholars opposed the Quran translation by non-Muslim because the translation would eliminate i'jaz al-Quran. However, this opposition did not affect other scholars to continue the effort of translating the Quran. Woolworth stated as cited by Betty Mauli and Rika Astari (2018), there are Quran translations had been done by non-Muslim, such as George Sale and Alexander Ross who were not affected with the controversy developed in the Muslim scholars' circle. It is because the early effort of non-Muslim translator encouraged Muslim outside the Arab world to translate Quran into their languages. The importance of Quran as devine scripture and supreme authority of Muslim; Arab and non-Arab, is an essential motivation for this initiative.

\section{Translation Strategy}

Domestication and foreignization are strategies which encompass the direction of translator while dealing with the source text. These strategies were first introduced by the German philosopher and theologian Friedrich Schleiermacher in his lecture in 1813 "On the Different Methods of Translating" (Schleiermacher, 1813/1992). The purpose of domestication is to bring the text close to the readership by reducing the foreignness of cultural values, while the foreignization is strategy that bring the author close to the readership by remaining this foreignness of cultural values. According to Venutti (1995), to avoid cultural clashes, he suggests applying the foreignization as solution for cultural problems in translation. This remarks a question whether the domestication is less functional or effective than foreignization.

\section{Cultural Element}

Translation scholars have determined the categorizations of cultural element as proposed by Nida (1964) and Newmark (1988). Many cultural-loaded words have abundant meanings, and it is not easy task to choose the appropriate one. The words in source language carry more layers of meaning than those in target language, especially the word which related to religion as a major component in any culture. This 
becomes crucial in translation, when a translator from a different culture attempts to convey the meaning into another culture that he or she may not understand adequately which leads to misinterpretation.

\section{Componential Analysis}

Componential analysis focuses on the study of lexical-semantic relation of word as the research subject. Semanticist divides the content words into many sense components to make a fundamental comparison with each word. Generally, componential analysis is more applicable to different words in the same semantic field (Yu \& Liang, 2016). In translation, componential analysis is the basic comparison of a source language word with a target language word which has a similar meaning, but not an obvious oneto-one equivalent, by demonstrating first their common and then their differing sense components (Newmark, 1988:115). Therefore, employment of componential analysis would serve a solution while dealing with cultural gap and clashes.

\section{Methodology}

This is qualitative study, and the data are analyzed descriptively using document analysis method in collecting and analyzing the data of religious cultural elements. Process of collecting data involved 3 phases; extracting the data from primary and secondary sources, then screening the data by determining some exclusions which helps in identifying specific data. Later, the data were categorized based on 6 Pillars of Iman; Allah, al-Malaikah, al-Kitab, al-Rasul, al-Yaum al-Akhir and al-Qada' wa al-Qadr. In analyzing the data, the study implemented componential analysis and data validation with the exegesis. Figure 1 below illustrates the methodology applied in the study:

Figure 1: Methodology of the Study

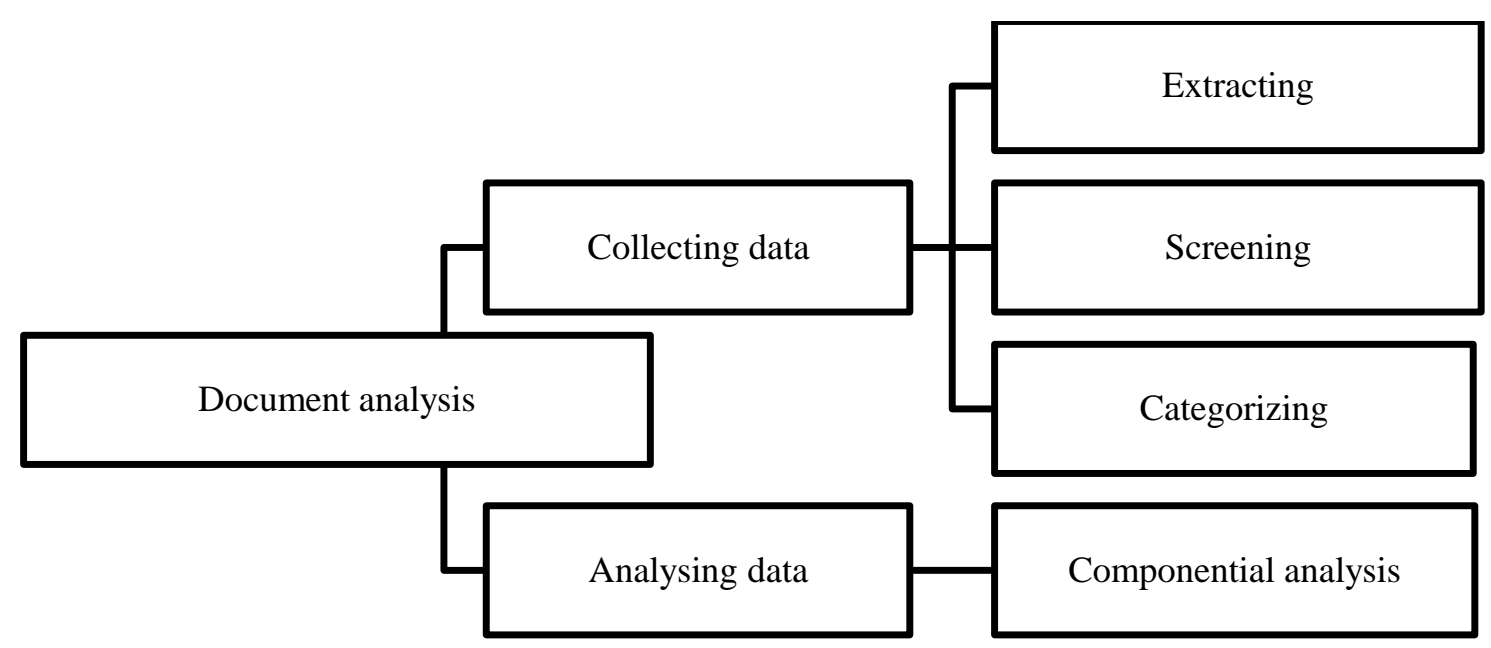

Figure 2 shows the procedure conducted in collecting data which consists of 3 different phases. The study adopted 3 phases of thematic analysis by Braun and Clark (2006). First phase involved the extraction of data from Baqarah chapter that are only related to Pillars of Iman. There are 2 types of data, the former is primary data; religious cultural elements of Pillars of Iman from the Quran (source text), whilst the latter is secondary data from English Quran translation by Seyyed Hossein Nasr (ed.in chief, 2017), namely The Study Quran (target text).

In the second phase, those data were screened by excluding words which are not noun and consist of more than single word. This explains that data of Pillars of Iman which consist of more than a word such as phrase is excluded. Finally, those data were categorized into 6 elements but only 4 of them are analyzed in the study and they are Allah, al-Malaikah, al-Kitab and al-Rasul. The other 2 elements; al- 
Yaum al-Akhir and al-Qada' wa al-Qadr were not included for some justifications, firstly; these 2 elements have different references in the Qura $\mathrm{n}$ and had been discussed widely among scholars. There is no specific and direct reference for this element, or no one-to-one word represent its meaning like the 4 former elements. Thus, the study only emphasized on these 4 elements.

Figure 2: Data Collecting Procedure

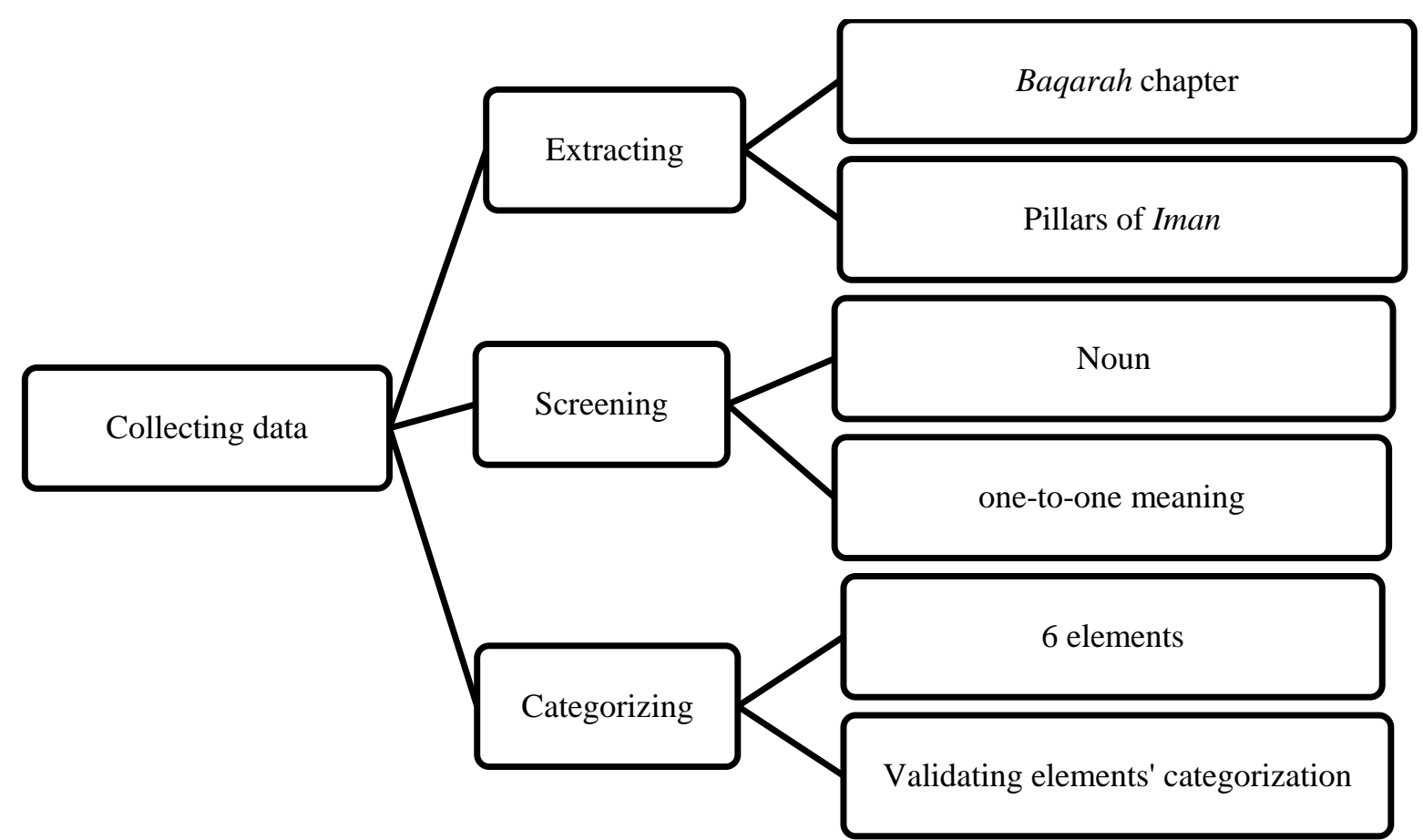

In disclosing the meaning of domesticated equivalent, the study adopts componential analysis (Newmark, 1988). The meaning of selected elements was extracted from the ST and the TT, then, analyzed based on the characteristic which were explained in the exegesis. In this sense, the study selected the commentary of al-Tabari (d.310/923) to validate the meaning accuracy of equivalent given in the target language. The prominence of this exegesis is the reason behind its selection in the study.

The reason of those meanings validated with exegesis is they were translated into English using domestication strategy. The purpose of this strategy is to bring the text close to the reader. Yet, the domesticated equivalent does not carry the same degree of meaning as intended in the Quran. There are some characteristics disappeared from the selected equivalent. Thus, it must be validated with exegesis to ensure the meaning accuracy provided in the target text.

Figure 3: Data Analyzing Procedure

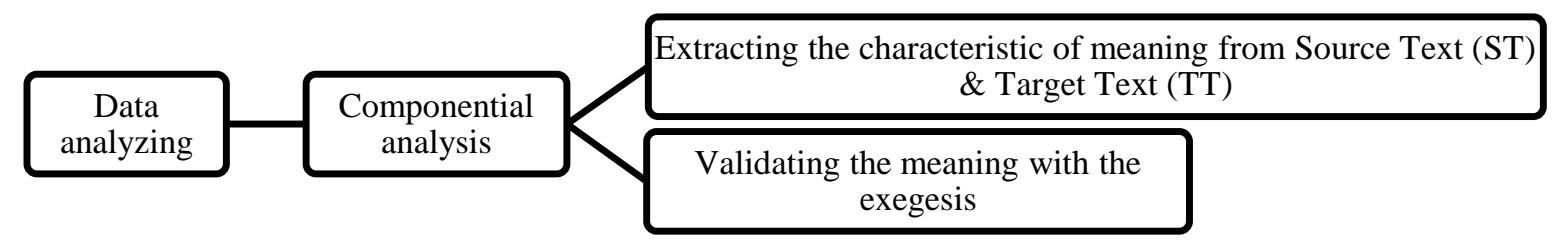

\section{Result}

The data of the study involve religious cultural elements that are related to 6 Pillars of Iman i.e., Allah, al-Malaikah, al-Kitab, al-Rasul, al-Yaum al-Akhir and al-Qada' wa al-Qadr. However, the study only extracted 4 pillars, to be exact: Allah, al-Malaikah, al-Kitab and al-Rasul. Al-Yaum al-Akhir and alQadha' and al-Qadar are excluded from the study. 
Table 1: Data of Religious Cultural Elements in al-Baqarah chapter

\begin{tabular}{cccl}
\hline $\begin{array}{c}\text { Tota } \\
\text { l }\end{array}$ & ST & TT & \multicolumn{1}{c}{ FOOTNOTE } \\
\hline 165 & Allah & God & $\begin{array}{l}\text { the absolute and divine Oneness, no equality with His Essence } \\
\text { or Self, no sonship and self-sufficient independent Being } \\
\text { spread God's revealed books, sent to the Messengers of Allah, } \\
\text { discriminate between truth and falsehood, lawful and } \\
\text { unlawful, anddescend with the revelation }\end{array}$ \\
5 & al-Malaikah & Angels & $\begin{array}{l}\text { Quran, Torah, Gospel } \\
\text { Prophets or who came with Holy Books or taught its law and } \\
\text { teachings }\end{array}$ \\
\hline 10 & $\begin{array}{l}\text { al-Kitab } \\
\text { al-Rasul }\end{array}$ & Booksenger \\
\hline
\end{tabular}

The previous table illustrates the data of Pillars of Iman; Allah, al-Malaikah, al-Kitab and al-Rasul. These pillars are considered religious cultural elements for its uniqueness and peculiarity of unseen characteristics which specify only to the religion of Islam. There are 202 words in total extracted from Baqarah chapter that refer to the pillars.

\section{Discussion}

It is apparent that these elements were domesticated by using the common-target-culture words that somehow has similar meaning. For instances, Allah was translated into God, al-Malaikah into Angel, al-Kitab into Book and al-Rasul into Messenger. However, those equivalents do not carry the same characteristic and descriptions as implied in the Quran. Those are only partial adequate meanings for fractional or limited of accuracy.

Those equivalents cannot stand alone in conveying the intended meaning. The reason is that the unseen characteristics which expressed in these elements are conceptual beliefs that go beyond human minds. Therefore, the translator came with compensation strategy by providing footnote to help the reader to adequately understand the source text meaning. It can be assumed that domesticating word in target culture can remain the foreignness values of source text, if compensation strategy is applied in the translation particularly for sensitive text such as religious text.

\section{Conclusion}

Domestication as strategy in translation can provide adequate meaning in target culture, but it must come with compensation strategy. It is because the equivalent does not carry the similar meaning of its original as it is conceptualized in the target culture. Therefore, the footnote provided is very helpful for better understanding. This explains that the foreignness of the original will be reduced when the word is domesticated. However, compensation strategy will help to close the cultural gap and its ambiguity. It can be concluded that the combination of compensation and domestication as strategies are fruitful in providing adequate meaning of equivalent.

On the other hand, componential analysis would serve as a solution when dealing with religious cultural element. It is because the adoption of this analysis could identify the specific meaning and range of context of word in translated version including level of equivalent degree. In analyzing the meaning of equivalent especially of religious text, it is suggested to do validating it characteristic with exegesis and expert of seminal work.

In the context of translating religious cultural elements or religion-culture-specific items, the study strongly suggests that compensation strategy is essential and compulsory as the effort to help the reader understands the meaning at the same degree as well as the knowledge could be disseminated adequately. 
Based on the conducted analysis, the study discovered that domestication as strategy be able to provide the adequate meaning in target language, but it cannot stand alone in rendering the meaning. Thus, the study proposes that the domestication strategy must be integrated with the compensation strategy which will supply the meaning sufficiently, especially when the source text involves religious cultural elements for, they are considered as sensitive text which carry peculiar characteristics.

\section{References}

Abobaker Ali Brakhw \& Sharifah Fazliyaton Shaik Ismail. 2014. The Importance of the Holy Quran into English: Governing Factors in the Translating Process. Arab World English Journal, 3, 95104.

Adofo, S. (2013). Challenges And Coping Strategies Of Student Nursing Mothers In Tertiary Institutions In The Greater Accra Region Of Ghana (M.Phil). University of Ghana.

Ahmad Bazli Ahmad Hilmi et.al. (2014). Terjemahan al-Qur'an Bahasa Melayu: Penilaian Berasaskan Tafsīr 'Ilmī. Jurnal Usuluddin, 39, 111-133.

Ahmad von Denffer. (2010). History of the Translation of the Meanings of the Qur'an in Germany up to the Year 2000 A Bibliographic Survey. Journal of Qur'anic Research and Studies, 2(3), 5-62.

Al-Tabari, Jami' al-Bayan fi Ta'wil Aay al-Qur'an, (d.310/923).

Betty Mauli Rosa Bustam \& Rika Astari. (2018). Meaning Differences Between Two Quran Translations in Activism Era in Indonesia (Ideology in Translation Analysis). Journal of Social Science and Religion, http://dx.doi.org/10.18784/analisa.v3i1.602

Braun, Virginia and Clarke, Victoria, (2006). Using Thematic Analysis in Psychology. Qualitative Research in Psychology, 3(2), 77-101.

Elmarsafy, Z. (2009). The Enlightenment Qur'an: The Politics of Translation and The Construction of Islam. Oxford: One world Publications.

Gázquez, J. M. (Gray, A), Translations of the Qur'an and other Islamic texts before Dante (Twelfth and Thirteenth Centuries), Dante Studies with the Annual Report of the Dante Society, 2007, 125 (Dante and Islam), pp. 79-92.

Hackett, Conrad \& Lipka, Michael. (2018). The Demographic Factors that Make Islam the world's Fastest-growing Major Religious Group. Scripta Instituti Donneriani Aboensis, 28.10.30674/scripta.70064.

Iman Najim Abdul-Rahman Khalaf \& M.Y. Zulkifli bin Haji Mohd Yusoff. (2012). The Qur'an: Limits of Translatability. Quranica International Journal of Quranic Research, 73-85.

Islam the World's Fastest Growing Religion. (2017). Retrieved from Newshttps://www.bbc.com/news/av/world-39279631

Mohd Shukri Hanapi. (2001). Usaha Penterjemahan al-Quran di Kepulauan Melayu, Jurnal Pemikir, 26, 173-197.

Nasr, Seyyed Hossein. (2015). The Study Quran. USA: Harper Collins Publishers.

Newmark, P. (1988). A Textbook of Translation. London: Longman Ltd.

Nida, E. (1964). Towards a Science of Translation, with special reference to principles and procedures involved in Bible translating. Leiden: E.J. Brill, Leiden.

Schleiermacher, F. (1813/1992). On the different methods of translating. In R. Schulte and J. Biguenet (eds.).

Venutti, L. (1995). The Translator's Invisibility. London/New York: Routledge.

Yu Checn-chen \& Liang Jin-zhu. (2016). The Functions of Componential Analysis to the Translation of Cultural Animal Images in The Classic of Mountains and Seas, Sino-US English Translation, 13(9), 724-735. 